IZA DP No. 841

Skill-Biased Technical Change in U.S.

Manufacturing: A General Index Approach

Badi H. Baltagi

Daniel P. Rich

August 2003 


\title{
Skill-Biased Technical Change in U.S. Manufacturing: A General Index Approach
}

\author{
Badi H. Baltagi \\ Texas A\&M University and IZA Bonn \\ Daniel P. Rich \\ Illinois State University \\ Discussion Paper No. 841 \\ August 2003 \\ IZA \\ P.O. Box 7240 \\ D-53072 Bonn \\ Germany \\ Tel.: +49-228-3894-0 \\ Fax: +49-228-3894-210 \\ Email: iza@iza.org
}

\begin{abstract}
This Discussion Paper is issued within the framework of IZA's research area Mobility and Flexibility of Labor. Any opinions expressed here are those of the author(s) and not those of the institute. Research disseminated by IZA may include views on policy, but the institute itself takes no institutional policy positions.
\end{abstract}

The Institute for the Study of Labor (IZA) in Bonn is a local and virtual international research center and a place of communication between science, politics and business. IZA is an independent, nonprofit limited liability company (Gesellschaft mit beschränkter Haftung) supported by Deutsche Post World Net. The center is associated with the University of Bonn and offers a stimulating research environment through its research networks, research support, and visitors and doctoral programs. IZA engages in (i) original and internationally competitive research in all fields of labor economics, (ii) development of policy concepts, and (iii) dissemination of research results and concepts to the interested public. The current research program deals with (1) mobility and flexibility of labor, (2) internationalization of labor markets, (3) welfare state and labor market, (4) labor markets in transition countries, (5) the future of labor, (6) evaluation of labor market policies and projects and (7) general labor economics.

IZA Discussion Papers often represent preliminary work and are circulated to encourage discussion. Citation of such a paper should account for its provisional character. A revised version may be available on the IZA website (www.iza.org) or directly from the author. 
IZA Discussion Paper No. 841

August 2003

\section{ABSTRACT \\ Skill-Biased Technical Change in U.S. Manufacturing: A General Index Approach}

This article applies recent advances in productivity and efficiency measurement to the evaluation of skillbiased technical change. Using the general index approach we are able to establish an explicit and unconstrained time path for nonneutral technical change between production and nonproduction labor in U.S. manufacturing industries over the 1959-1996 period. Our findings confirm the prevailing interpretation in the labor economics literature that substantial reductions in the relative share of production labor are attributable to a sustained period of nonneutral technical change. However, we find that skill-biased technical change effects are most evident prior to 1983. This predates the diffusion of personal computer technologies in the workplace and the dramatic wage structure changes associated with the 1980's. In contrast to prevailing alternatives, the general index approach also permits us to explain observed shifts in relative labor demand as a combination of price-induced substitution, nonhomothetic output effects and skill-biased technical change responses to a range of proposed elements.

JEL Classification: J23, C33, O33

Keywords: skill biased technical change, nonneutral technical change, labor demand, manufacturing, panel data, skill, wage inequality, general index of technical change

Corresponding author:

Badi H. Baltagi

Department of Economics

Texas A\&M University

College Station

Texas 77843-4228

USA

Tel.: +19798457380

Email: badi@econmail.tamu.edu 


\section{Introduction}

Labor demand responses to technical change have long been suspected of playing a key role in recently observed patterns of relative earnings inequality. Murphy and Welch (1992) establish increasing returns to education in the U.S. over the 1980's that appear especially dramatic for young workers. Given that relative supply of educated labor increased over an extended period as well, a consistent implication is that relative labor demand for educated labor (or skill) has risen. Bound and Johnson (1992) and Berman, Bound and Griliches (1994) among others infer skill-biased technical change (SBTC) as a primary source of the implied labor demand shifts through elimination of proposed alternatives. Recent reviews, including Johnson (1997) and Acemoglu (2002), highlight the relationship between workplace diffusion of information technologies and labor market outcomes as a topic of particular interest.

Berman, Bound and Griliches (1994) provide an essential contribution to this literature in three ways. First, they identify relative employment and cost share declines for production workers within (as opposed to between) detailed U.S. manufacturing industries. This adds indirect evidence for the role of SBTC in labor demand shifts over the $1979-87$ period. Berman, Bound and Machin (1998) find a similar pattern in the manufacturing sectors of a number of advanced countries. Again, the share of relatively skilled workers in total wage costs and employment appears to have increased and most of the shifts appear to have occurred within rather than between industries. They conclude that SBTC was pervasive over the past two decades, occurring simultaneously in most, if not all, developed countries.

Second, Berman, Bound and Griliches introduce a relative labor demand specification that includes proxy variables for sources of technical change. This empirical approach continues to serve as the standard for subsequent research on skill-biased labor demand responses. Machin and Van Reenen (1998), for example, find a significant association between skill upgrading and a directly observed measure of technical change, R\&D intensity, in seven OECD countries over the 1973-89 period. Doms, Dunne and 
Troske (1997) employ the relative share equation to document plant-level relationships between workforce skills and adoption of advanced manufacturing technologies.

Third, Berman, Bound and Griliches are frequently cited as providing a direct link from industrylevel investments in personal computers to within-industry labor demand shifts. They find that U.S. manufacturing industries with the highest rates of computer investments in the 1980's also experienced the greatest relative increase in nonproduction labor share. Berman, Bound and Machin (1998) proclaim "taken together, the evidence implicates microprocessors as a principal cause of SBTC throughout the developed world in the 1980's." They note, however, that these same industries also account for a substantial share of "within industry upgrading in the 1970's." An appreciation for related historical patterns, according to Berman, Bound and Griliches, would "suggest that we avoid exaggerating the uniqueness of the computer revolution."

Traditional analyses of factor demand with nonneutral technical change (NNTC), as developed in the production literature, have been conspicuously absent from this line of inquiry. Binswanger (1974) implements parametric tests for NNTC among multiple production inputs by introducing input-specific trends in the factor share equations of a flexible cost system. Such an approach offers a number of advantages in isolating and testing for technical change biases in the context of the full range of labor demand determinants. One would expect to see this approach featured prominently in a literature exploring labor demand shifts, not to mention a literature in search of NNTC in the form of SBTC. However, the measure of technical change bias is a path-constrained trend that does not lend itself to evaluation of underlying sources, a question of continuing interest.

We demonstrate how this shortcoming can be overcome with a general index approach to technical change measurement, as put forth by Baltagi and Griffin (1988). An explicit and unconstrained time path for SBTC is estimated in the context of a fully-specified factor demand system. System-based tests for 
NNTC, as well as estimates relating to the full range of primary labor demand determinants, facilitate subsequent evaluation of an unprecedented range of proposed technical change sources. Thus, in contrast to the previous literature, we are able to consider both the nature and sources of labor demand responses from the perspective of the traditional production literature.

Our estimates clarify the timing of employment share changes between production and nonproduction labor in U.S. manufacturing industries over the 1959-96 period. We find that SBTC, as traditionally defined, is significant and most evident prior to 1983 . This precedes the relative wage decline for production workers, coincides with a period notable for an increase in the supply of skill and also predates much of the workplace diffusion of personal computers. Our estimates of SBTC serve as a basis for subsequent analysis of potential sources. Investments in instruments for measurement, analysis, display, and process control represent an unheralded source of technical change. We also identify skillbiased responses to current investments in communications equipment, personal computers, software, and to a lesser extent industrial equipment and outsourcing. A substantial portion of measured technical change remains unexplained. While these findings are valuable on their own, the general index approach to evaluating the nature and sources of NNTC represents a general contribution to the SBTC literature.

We begin with a review of alternative approaches in section II. Factor demand system estimates based on detailed U.S. manufacturing industries over 1959-96 are presented in section III. Proposed sources of measured SBTC are evaluated in section IV where we also address how our results can be reconciled with previous findings. The final section offers concluding observations.

\section{Alternative Specifications}

Nonneutral Technical Change with Trend

Nonneutral technical change yields a change in the marginal rate of substitution between inputs for 
a given ratio of input use. However, the traditional measure of technical change is defined, in large part, by what is not explained by other variables. To isolate NNTC as a time-oriented residual it is necessary to control for all relevant output and input price effects (Binswanger 1974). Empirical specification becomes critical as any unwarranted restrictions on these input demand responses may lead to biased estimates of technical change effects.

For purposes of comparison, we employ a translog cost function that explicitly posits nonhomothetic output effects and flexible responses to input prices. This familiar second order approximation appears throughout the SBTC literature to the exclusion of alternative functional specifications. The production literature relating to NNTC refers to a wider range of flexible forms. For example, Binswanger (1974), Kumbhakar (2002) and Thomsen (2000) implement "factor-augmenting" technical change using second order, third order and alternative functional forms. Consider the natural logarithm of total costs $(\ln \mathrm{TC})$ as a function of all input prices $\left(\ln \mathrm{P}_{\mathrm{i}}\right)$, output $(\ln \mathrm{Y})$, and a time trend $(\mathrm{t})$.

$$
\begin{gathered}
\ln \mathrm{TC}=\alpha_{0}+\alpha_{\mathrm{y}} \ln \mathrm{Y}+\alpha_{\mathrm{t}} \mathrm{t}+\Sigma_{\mathrm{i}} \alpha_{\mathrm{i}} \ln \mathrm{P}_{\mathrm{i}}+1 / 2 \gamma_{\mathrm{yy}}(\ln \mathrm{Y})^{2}+1 / 2 \gamma_{\mathrm{yt}} \mathrm{t} \ln \mathrm{Y} \\
+1 / 2 \gamma_{\mathrm{tt}} \mathrm{t}^{2}+1 / 2 \Sigma_{\mathrm{i}} \Sigma_{\mathrm{j}} \gamma_{\mathrm{ij}} \ln \mathrm{P}_{\mathrm{i}} \ln \mathrm{P}_{\mathrm{j}}+\Sigma_{\mathrm{i}} \gamma_{\mathrm{iy}} \ln \mathrm{P}_{\mathrm{i}} \ln \mathrm{Y}+\Sigma_{\mathrm{i}} \gamma_{\mathrm{it}} \mathrm{t} \ln \mathrm{P}_{\mathrm{i}}
\end{gathered}
$$

Where $\mathrm{i}$ and $\mathrm{j}$ denote inputs which in our case include production and non production labor, capital, energy and material. Binswanger (1974, p. 966) enumerates the conditions required for a well-behaved cost function. Technical change, as represented in this second order approximation, may be nonlinear $\left(\gamma_{\mathrm{tt}}\right)$, scale-augmenting $\left(\gamma_{\mathrm{yt}}\right)$, and nonneutral $\left(\gamma_{\mathrm{it}}\right)$. Using Shephard's lemma, the corresponding demand for the $\mathrm{i}^{\text {th }}$ input is expressed in terms of input cost share 


$$
\mathrm{S}_{\mathrm{i}}=\mathrm{P}_{\mathrm{i}} \mathrm{X}_{\mathrm{i}} / \mathrm{TC}=d \ln \mathrm{TC} / d \ln \mathrm{P}_{\mathrm{i}}=\alpha_{\mathrm{i}}+\Sigma_{\mathrm{j}} \gamma_{\mathrm{ij}} \ln \mathrm{P}_{\mathrm{j}}+\gamma_{\mathrm{iy}} \ln \mathrm{Y}+\gamma_{\mathrm{it}} \mathrm{t}
$$

where input-specific technical change is identified after controlling for price-induced substitution $\left(\gamma_{\mathrm{ij}}\right)$ and nonhomothetic $\left(\gamma_{\text {iy }}\right)$ output responses.

In this context, nonneutral technical change implies unequal responses to $t$ across the different inputs. Binswanger (1974), for example, finds technical change in U.S. agriculture over 1949-64 to be labor-saving and machinery using. Betts (1997) estimates a system of translog cost shares based on equation (2) for Canadian manufacturing industries over the 1962-86 period, finding the pattern of NNTC to be labor-saving and factor-using for both capital and energy.

Skill-biased technical change involves unequal responses between specific categories of labor, which might be differentiated by education, occupation, or skill level. We can express the relative demand between production labor (p) and nonproduction labor (n) as the difference in cost shares

$$
\left(S_{p t}-S_{n t}\right)=\left(\alpha_{p}-\alpha_{n}\right)+\Sigma_{j}\left(\gamma_{p j}-\gamma_{n j}\right) \ln P_{j t}+\left(\gamma_{p y}-\gamma_{n y}\right) \ln Y_{t}+\left(\gamma_{p t}-\gamma_{n t}\right) t
$$

Betts (1997) rejects skill-neutrality $\left(\gamma_{\mathrm{pt}}-\gamma_{\mathrm{nt}}=0\right)$, finding technical change to be relatively production labor-saving in ten of eighteen industries. It should be noted that relative share changes due to price and output responses, as expressed in (3), can be substantial and nearly offset the SBTC effects over the period studied by Betts. Trend-based estimates of technical change for disaggregate labor are also found in the dynamic factor demand studies of Morrison and Berndt (1981) and Nissim (1984).

This traditional approach to econometric evaluation of NNTC provides for flexible functional form estimation of price-induced substitution and output responses. The general production specification 
comes, however, at the expense of a restrictive characterization of technical change. In the translog system NNTC is represented by a linear trend. When technical change is fit to a specific functional pattern (linear, quadratic, other) the path-constrained time series is ill-suited as the basis for evaluation of timing or potential sources.

\section{Relative Labor Demand with Proxy}

Overriding interest in the sources of SBTC has enticed the overwhelming majority of researchers in this area to replace the time-oriented term described above with one or more proxy measures $(Z)$ for proposed sources of technical change. When combined with the treatment of capital as quasi-fixed this implies the following variable cost (or partial static equilibrium) specification

$$
\begin{aligned}
\ln \mathrm{VC}= & \alpha_{0}+\alpha_{\mathrm{y}} \ln \mathrm{Y}+\alpha_{\mathrm{k}} \ln \mathrm{K}+\Sigma_{\mathrm{i}} \alpha_{\mathrm{i}} \ln \mathrm{P}_{\mathrm{i}}+\alpha_{\mathrm{z}} \mathrm{Z}+1 / 2 \gamma_{\mathrm{yy}}(\ln \mathrm{Y})^{2}+1 / 2 \gamma_{\mathrm{kk}}(\ln \mathrm{K})^{2} \\
& +1 / 2 \gamma_{\mathrm{yk}} \ln \mathrm{K} \ln \mathrm{Y}+1 / 2 \gamma_{\mathrm{zz}}(\mathrm{Z})^{2}+1 / 2 \gamma_{\mathrm{kz}} \mathrm{Z}_{\mathrm{t}} \ln \mathrm{K}+1 / 2 \gamma_{\mathrm{yz}} \mathrm{Z} \ln \mathrm{Y} \\
& +1 / 2 \sum_{\mathrm{i}} \sum_{\mathrm{j}} \gamma_{\mathrm{ij}} \ln \mathrm{P}_{\mathrm{i}} \ln \mathrm{P}_{\mathrm{j}}+\sum_{\mathrm{i}} \gamma_{\mathrm{iy}} \ln \mathrm{P}_{\mathrm{i}} \ln \mathrm{Y}+\sum_{\mathrm{i}} \gamma_{\mathrm{ik}} \ln \mathrm{P}_{\mathrm{i}} \ln \mathrm{K}+\sum_{\mathrm{i}} \gamma_{\mathrm{iz}} \mathrm{Z}_{\mathrm{t}} \ln \mathrm{P}_{\mathrm{i}}
\end{aligned}
$$

Factor shares are derived from the variable cost function through Shephard's lemma. For each of the remaining variable inputs this yields

$$
\mathrm{S}_{\mathrm{i}}=\alpha_{\mathrm{i}}+\Sigma_{\mathrm{j}} \gamma_{\mathrm{ij}} \ln \mathrm{P}_{\mathrm{j}}+\gamma_{\mathrm{iy}} \ln \mathrm{Y}+\gamma_{\mathrm{ik}} \ln \mathrm{K}+\gamma_{\mathrm{iz}} \mathrm{Z}
$$

Cost share variation attributed to $\mathrm{Z}$ after controlling for price, capital and output responses would be identified as input-specific technical change. Nonneutral technical change is affirmed by unequal responses to the proxy $(Z)$ across different variable inputs. It is clearly important to obtain appropriate 
proxies for technical change that are reasonably comprehensive in their representation of sources and uncorrelated with any significant omissions.

Levy and Jondrow (1986) estimate a translog system based on (4) and (5) for U.S. steel and auto industries over the 1959-80 period. For the steel industry, they incorporate direct measures of industryspecific process innovations: basic oxygen furnace adoption, oxygen lancing in open-hearth furnaces, pelletization of iron ore and continuous casting. Levy and Jondrow find technical change capital-using and production labor-saving; however, they also document substantial employment responses to output and a full range of input prices. The relative labor demand expression (6) emphasizes this range of primary influences

$\left(S_{p t}-S_{n t}\right)=\left(\alpha_{p}-\alpha_{n}\right)+\Sigma_{j}\left(\gamma_{p j}-\gamma_{n j}\right) \ln P_{j t}+\left(\gamma_{p y}-\gamma_{n y}\right) \ln Y_{t}+\left(\gamma_{p k}-\gamma_{n k}\right) \ln K_{t}+\left(\gamma_{p z}-\gamma_{n z}\right) Z_{t}$

Berman, Bound and Griliches (1994) explore relative labor demand movements between production and nonproduction workers within U.S. manufacturing industries in the 1980's. They consider an amended version of equation (6), imposing the additional assumptions of constant returns to scale and homogeneity of degree one in prices. This yields the reduced form single equation

$$
\Delta \mathrm{S}_{\mathrm{n}}^{*}=\beta_{0}+\beta_{1} \Delta \ln \left(\mathrm{P}_{\mathrm{n}} / \mathrm{P}_{\mathrm{i}}\right)+\beta_{2} \Delta \ln (\mathrm{K} / \mathrm{Y})+\beta_{3} \Delta \mathrm{Z}
$$

where $\Delta \mathrm{S}_{\mathrm{n}}{ }^{*}$ is the first difference of nonproduction share in labor costs. An advantage of this form is the reliance on capital investment data as opposed to the more complicated (and perhaps tenuous) construction of capital stock or user cost measures. It should also be noted that Berman, Bound and 
Griliches drop the relative wage term in (7) out of concern for endogeneity. As a result, their estimated equation provides no control for price-induced substitution. This could produce biased estimates of SBTC $\left(\beta_{3}\right)$ if relative price movements are correlated with the proxy variable.

A frequently cited result from this study involves computer investments as a proxy $(Z)$ for the sources of technical change. To the extent that omitted sources are significant and correlated with the growth of computer investments there is a potential for estimation bias. Levy and Jondrow (1986) implement alternative specifications, a single proxy and a trend, for U.S. auto manufacturing and offer a cautionary note. Their test results for NNTC, as well as price and output parameter values, are not robust to technical change specification.

\section{A General Index Approach}

The preceding discussion suggests a tradeoff between the desirable econometric properties of traditional trend estimates and the gains in interpretation anticipated through the relative demand approach in equation (7). The general index approach to technical change measurement, as put forth by Baltagi and Griffin (1988), conveys the advantages of both alternatives. See Baltagi, Griffin and Rich (1995) for a related application of this approach.

Consider either the total cost equation (1) or variable cost equation (4) and redefine the time element as an index of technical change $\mathrm{A}(\mathrm{t})$, unconstrained with regard to time path, which is itself a function of an array of sources $(Z)$. We can implement $A(t)$ as a set of time specific dummy variables $D_{t}$ conditional on the availability of panel data. In the total cost case we now have

$$
\ln \mathrm{TC}=\Sigma_{\mathrm{t}} \eta_{\mathrm{t}} \mathrm{D}_{\mathrm{t}}+\alpha_{\mathrm{y}} \ln \mathrm{Y}+\Sigma_{\mathrm{i}} \alpha_{\mathrm{i}} \ln \mathrm{P}_{\mathrm{i}}+1 / 2 \Sigma_{\mathrm{t}} \gamma_{\mathrm{yt}} \mathrm{D}_{\mathrm{t}} \ln \mathrm{Y}+1 / 2 \gamma_{\mathrm{yy}}(\ln \mathrm{Y})^{2}
$$




$$
+\Sigma_{\mathrm{i}} \gamma_{\mathrm{iy}} \ln \mathrm{P}_{\mathrm{i}} \ln \mathrm{Y}+1 / 2 \Sigma_{\mathrm{i}} \Sigma_{\mathrm{j}} \gamma_{\mathrm{ij}} \ln \mathrm{P}_{\mathrm{i}} \ln \mathrm{P}_{\mathrm{j}}+\Sigma_{\mathrm{i}} \Sigma_{\mathrm{t}} \gamma_{\mathrm{it}} \mathrm{D}_{\mathrm{t}} \ln \mathrm{P}_{\mathrm{i}}
$$

As before, we derive total cost factor shares as

$$
S_{i}=\alpha_{i}+\Sigma_{j} \gamma_{i j} \ln P_{j}+\gamma_{i y} \ln Y+\Sigma_{t} \gamma_{i t} D_{t}
$$

where the $\gamma_{\text {it }}$ parameters in the final term represent a series of time-oriented residual estimates. Thus, the time path of input-specific technical change is not constrained to fit a particular pattern over time or tied to the time path of a particular set of observable proxy variables.

The question of NNTC is somewhat flexible in this context, including the possibility of selecting a limited subperiod within the overall sample for evaluation. Once again, SBTC is simply a special case of NNTC involving unequal responses between specific categories of labor. The relative demand between production labor (p) and nonproduction labor (n) is

$$
\left(S_{p t}-S_{n t}\right)=\left(\alpha_{p}-\alpha_{n}\right)+\Sigma_{j}\left(\gamma_{p j}-\gamma_{n j}\right) \ln P_{j t}+\left(\gamma_{p y}-\gamma_{n y}\right) \ln Y_{t}+\Sigma_{t}\left(\gamma_{p t}-\gamma_{n t}\right) D_{t}
$$

Here we see how the general index approach yields a separate estimate of SBTC $\left(\gamma_{\mathrm{pt}}-\gamma_{\mathrm{nt}}\right)$ in each time period. Consistent with traditional residual approaches, technical change is identified by what is not explained through other primary input demand variables.

The general index approach would appear to avoid the omitted variable hazard associated with the popular reliance on proxy variables and produce residual measures of technical change that are not tied to one or more observable series. At the same time, this approach provides a useful alternative to trend-based 
approaches, producing unconstrained time paths for input-specific technical change that facilitate evaluation of a wide range of proposed sources.

\section{Production and Nonproduction Labor Demand}

\section{Manufacturing Data and System Estimation}

The National Bureau of Economic Research (NBER) manufacturing productivity database file provides annual data on 459 manufacturing industries at the SIC 4-digit level. The Annual Survey of Manufactures (an annual survey of 60,000 manufacturing establishments) and Census of Manufactures (conducted at five year intervals), both administered by the U.S. Census Bureau, are the primary sources for most of this data. Our full sample period consists of 17,432 observations over the period 1959-96. The demise of asbestos products manufacturing (SIC 3292) along with unreported values for nonproduction labor in other scattered cases (SIC 2384, 2395, 3263) leave us 10 observations short of a balanced panel. All data on production labor, nonproduction labor, energy, materials and output are derived from the NBER files.

The updated NBER file provides industry estimates for capital stock, a product of the combined efforts of Federal Reserve Bank and Bureau of Economic Analysis personnel. The NBER also provides industry-specific price series for new capital investment. Additional series required to construct user cost of capital, consistent with Betts (1997) and the Bureau of Labor Statistics, are developed from a variety of

sources. These measures include the interest rate on corporate bonds, real capital gains, depreciation rate, present value of tax on depreciation, investment tax credit and tax rate on corporate income.

Production and nonproduction labor demand estimates are presented under six alternative specifications. We implement both total cost and variable cost versions of the trend, proxy and general index approaches. The full set of input cost share equations, as described in (2), (5) and (9), form the basis 
for estimation. Although there are five inputs, the number of equations estimated is reduced by one through symmetry and adding up conditions and by an additional one in the variable cost versions. Industry heterogeneity is acknowledged in similar fashion across all specifications through inclusion of fixed effects at the 2-digit SIC level in each estimated share equation.

For purposes of comparison, the proxy specifications are implemented with a single variable, the investment measure often referred to as "high-tech capital" (Morrison Paul and Siegel (2001)). The Bureau of Economic Analysis reports investments by asset class at the 2-digit SIC level. This measure is simply the annual ratio of investments in selected asset classes (computing equipment and software, communications equipment, scientific and engineering instruments, photocopy equipment and other office machinery) to total new investment.

In each case we estimate a system of share equations using the iterated seemingly unrelated regression estimation (ISURE) procedure in recognition of contemporaneous input demand choices. In other words, we do not assume that the residuals across share equations are uncorrelated. Among the advantages of system estimation is the opportunity for hypothesis testing through the imposition of crossequation constraints. We report the results of numerous likelihood ratio tests throughout the remainder of the paper. The entire system is estimated with and without the restriction in question with the difference in $\log$ likelihood values forming the basis for a chi-squared test. To evaluate the hypothesis of zero correlations among residuals across share equations we employ a chi-squared test based on the Lagrange multiplier derived by Breusch and Pagan (1980).

\section{Labor Demand Responses}

Factor demand system parameter estimates are reported in Table 1 for the total cost - general index specification. Estimation results are converted into familiar labor demand elasticities in Table 2 with the 
total cost - general index outcomes appearing in the third column. Elasticities are evaluated at every observation with annual elasticities developed as payroll-weighted means across industries. Reported elasticities are given as simple means across the annual values.

Own wage elasticities of labor demand ( $\left.d \ln \mathrm{X}_{\mathrm{i}} / d \ln \mathrm{P}_{\mathrm{i}}\right)$ for production and nonproduction workers are reasonable and robust across specifications. Employment responses to own wage and energy price changes appear somewhat more elastic for production workers. On the other hand, elasticity results for materials appear quite sensitive to technical change specification. Price-induced substitution responses are a potentially important source of changes in relative labor demand. Berman-Bound-Griliches and others impose the assumption that input price responses are identical across production and nonproduction workers. This hypothesis $\left(\gamma_{\mathrm{pj}}-\gamma_{\mathrm{nj}}=0\right.$, for all $\left.\mathrm{j}\right)$ is decisively rejected for all specifications on the basis of likelihood ratio tests. The corresponding chi-square statistics and .01 critical values are given in Table 2. Moreover, the Breusch-Pagan test for zero correlation of residuals across equations rejects the single equation approach prevalent in the labor economics literature in favor of system estimation.

It would be nice to know which of the three approaches to technical change measurement provides the most satisfactory overall estimates. A priori, there are no criteria by which we might view one set of estimates more reasonable than any other. Though not conclusive, equation-by-equation goodness of fit (rmse and r-squared) for the estimated labor demand equations consistently rank the general index first, the trend second and the proxy approach last.

Relative share estimates, consistent with equations (3), (6) and (10), are presented in Table 3. An input price with a positive sign would be a relative substitute (or less of a relative complement) for production labor. Energy and capital exhibit greater relative substitution with production labor than with nonproduction labor in the total cost specifications. Production labor is consistently more responsive to output in both trend and general index specifications. The related hypothesis of homothetic output 
responses across all inputs $\left(\gamma_{\text {iy }}=0\right.$, for all $\left.\mathrm{i}\right)$ is rejected below. Note that neither homotheticity nor constant returns to scale are imposed. This is a degree of generality that would typically be sacrificed if dynamic adjustment of quasi-fixed inputs were introduced (Morrison Paul and Siegel (2001)).

Table 3 also provides a summary of technical change findings across the alternative specifications. Hicks-neutral technical change across all inputs is decisively rejected, indicating NNTC (see Betts (1997, p. 148)). The underlying parameter estimates from Table 1 reveal input-specific technical change to be labor-saving and materials-using. Skill-neutral technical change between production and nonproduction labor is rejected as well for each of the six specifications. The hypothesis is expressed $\gamma_{\mathrm{pt}}-\gamma_{\mathrm{nt}}=0$ for trend-based estimates, $\gamma_{\mathrm{pz}}-\gamma_{\mathrm{nz}}=0$ for the proxy approach and $\gamma_{\mathrm{pt}}-\gamma_{\mathrm{nt}}=0$ for all $\mathrm{t}$ with the general index. While shares of both labor categories experience average annual declines associated with technical change, SBTC finds support in every case. This is not to say that all specifications yield the same estimates of technical change effects. Indeed, the proxy specifications indicate technical change responses of substantially smaller magnitudes than those found through the trend and general index approaches. Nonetheless, the relative labor demand response in all six cases is production labor-saving in absolute terms and relative to nonproduction labor.

\section{Path of Skill-Biased Technical Change}

There is a fundamental distinction between the alternative approaches. The time path of skillbiased technical change, in the proxy approach, relies on the estimated coefficients on the proxy variable in the labor share equations and on the observed time path of the proxy. Estimates of input bias derived from the trend approach will be time-invariant, despite the general flexibility of the cost function (Kumbhakar (2002, p.248)). In contrast, the estimated time path of skill-biased technical change using the general index approach is unconstrained with respect to observable variables and 
time.

An effective comparison between alternatives is displayed in Figures 1 and 2. Each series represents the cumulative effect of skill-biased technical change on relative factor shares of the two categories of labor. The pattern is quite similar in both the total cost and variable cost cases. The trend and general index indicate similar overall effects from SBTC exceeding that measured by the proxy approach. However, the general index provides substantial variation around the linear trend. The trend can be modeled as a special case of the general index, consistent with Kumbhakar (2002) in this context, by imposing $\gamma_{i t}=\beta_{\mathrm{i}} \mathrm{t}$ for each $\mathrm{i}$ and all $\mathrm{t}$ other than the initial period where $\gamma_{\mathrm{it}}=0$. The time period-specific parameters are constrained to a linear path with a constant difference between the year-to-year estimates of the general index in each of the share equations. This restriction is rejected for our sample of U.S. manufacturing industries. The associated chi-square statistics and .01 critical values (in parentheses) are 5212.9 (185.3) for the total cost specification and 3079.7 (143.9) for the variable cost specification.

Within the general index measure most of the SBTC appears to occur during the ten to fourteen years preceding 1983. This may seem a bit surprising given the focus of the SBTC discussion on the 1980's not on the 1970's. While we explore these matters further in the next section, a few immediate qualifications should be noted. First, the absence of SBTC does not preclude within-industry labor demand shifts. Second, relative wages are treated as exogenous in our analysis. Third, the data refer only to manufacturing production establishments and do not represent the economy as a whole. These three observations are important in reconciling our findings with the prevailing sense of labor demand patterns.

As mentioned previously, the general index supports meaningful point-to-point tests for SBTC effects. These can be implemented simply as linear combinations of general index parameter $\left(\gamma_{\mathrm{it}}\right)$ 
estimates. We form the expression $\left(\gamma_{\mathrm{pt}}-\gamma_{\mathrm{p}, \mathrm{t}-\mathrm{q}}\right)-\left(\gamma_{\mathrm{nt}}-\gamma_{\mathrm{n}, \mathrm{t}-\mathrm{q}}\right)$ where t-q represents the earlier comparison year. Based on the total cost specification we find statistical support for our visual interpretation of the series. As shown in Table 4, SBTC is evident for various subperiods throughout 1963-83. Skill-neutral technical change cannot be rejected for selected ranges over the 1983-96 period.

\section{Reconsidering Technical Change in U.S. Manufacturing}

Industry Heterogeneity

Our focus in the preceding sections has been on alternative estimates of the time path of skillbiased technical change common throughout U.S. manufacturing. What about heterogeneity of input choice and the industry-specific nature of nonneutral technical change? These become especially important considerations as we prepare to evaluate potential sources of skill bias over time across diverse industry settings.

A number of empirical approaches appear in the related labor demand literature. Betts (1997) implements an effective treatment of industry heterogeneity through estimation of separate equations for each of 16 manufacturing industries. However, feasibility requires that a trend restriction be imposed on the time path of technical change. Berman, Bound and Grilliches (1994), Morrison Paul and Siegel (2001) and others employ time-differenced share equations to control for industry heterogeneity. A prevalent concern in the production literature is that reducing the systematic variation in the data through differencing is undesirable and could exaggerate bias due to measurement error (Griliches and Hausman (1986), Roberts and Skoufias (1997)).

The alternative proposed by Baltagi, Griffin and Rich (1995) relies on the conceptual treatment 
of technical change as a residual. Adapting this approach to the present context permits us to develop industry-specific measures of nonneutral technical change for each factor of production. For the total cost - general index specification, the estimated system of factor share equations can be restated as

$$
\mathrm{S}_{\mathrm{ist}}=\alpha_{\mathrm{i}}+\Sigma_{\mathrm{j}} \gamma_{\mathrm{ij}} \ln \mathrm{P}_{\mathrm{jst}}+\gamma_{\mathrm{iy}} \ln \mathrm{Y}_{\mathrm{st}}+\mu_{\mathrm{ist}}
$$

where $\mu_{\text {ist }}$ is the error associated with each input (i), industry (s) and time period (t). The two-way error components can be expressed

$$
\mu_{\text {ist }}=A_{\text {it }}+\lambda_{\text {is }}+\varepsilon_{\text {ist }}
$$

in terms of input-specific time elements $\left(\mathrm{A}_{\mathrm{it}}\right)$, input-specific industry effects $\left(\lambda_{\text {is }}\right)$ and input-specific residuals $\left(\varepsilon_{\text {ist }}\right)$ corresponding to each observation. With panel data we are able to model the time and industry elements in fixed effects form

$$
\mathrm{S}_{\mathrm{ist}}=\alpha_{\mathrm{i}}+\Sigma_{\mathrm{j}} \gamma_{\mathrm{ij}} \ln \mathrm{P}_{\mathrm{jst}}+\gamma_{\mathrm{iy}} \ln \mathrm{Y}_{\mathrm{st}}+\Sigma_{\mathrm{t}} \gamma_{\mathrm{it}} \mathrm{D}_{\mathrm{t}}+\Sigma_{\mathrm{s}} \lambda_{\mathrm{is}} \mathrm{D}_{\mathrm{s}}+\varepsilon_{\text {ist }}
$$

The time dummies $\left(D_{t}\right)$ provide the general index estimates $\left(\gamma_{i t}\right)$ of input-specific technical change effects across U.S. manufacturing. In contrast to the trend approach there is no constraint imposed on the time path of these estimates. Following Roberts and Skoufias (1997) we adopt industry fixed effects $\left(D_{s}\right)$ at the two-digit SIC level with estimates of $\lambda_{\text {is }}$ relating to input efficiency specific to industry s and invariant to 
time. The remaining error component $\varepsilon_{\text {ist }}$ is an input-specific random disturbance unique to the detailed industry and time period. The theoretically-motivated potential for correlation among the $\varepsilon_{\text {ist }}$ errors across the $\mathrm{i}$ input share equations is provided for through the iterated seemingly unrelated regression estimation (ISURE) procedure.

The $\mu_{\text {ist }}$ indicated in equation (12) can be reconstructed by combining the $A_{i t}$ series with fixed industry effects $\left(\lambda_{\text {is }}\right)$ and first round input demand residuals, taken as estimates of $\varepsilon_{\text {ist. }}$ The resulting inputspecific indices of technical change form a panel of estimates that serve as the basis for subsequent analysis. These residual-based input-specific indices are not constrained to follow the same time path across industries. Table 5 presents a summary of the resulting indices for U.S. manufacturing industries in terms of the implied average annual pace of skill-biased technical change over the 1959-1996 period.

There is substantial variation in SBTC across 2-digit industries ranging from -.0054 in printing and publishing to -.0025 in food and kindred products. The order of presentation in Table 5 is based on the contribution to the payroll-weighted average of -.0039 across manufacturing. That is, industries with a relatively large proportion of total manufacturing payroll and an average or above average pace of SBTC appear toward the top. The variation across 4-digit industries is greater ranging from -.0108 in the manufacture of accounting machines ((SIC 3578, including point-of-sale devices, fund transfer devices and automated teller machines) to +.0012 in bottled and canned drinks (SIC 2086, including carbonated water, fruit juice, soft drinks and beer). With this industry-specific measure exceeding zero for only four of 459 industries, the general finding of SBTC for U.S. manufacturing would appear relatively robust to industry heterogeneity concerns.

\section{Evaluating Proposed Sources}

Estimates of nonneutral technical change effects throughout U.S. manufacturing are captured in $\mathrm{A}_{\mathrm{it}}$, 
the derivative of the $i^{\text {th }}$ input demand with respect to time. First round parameter estimates are used to develop $A_{i t}$ series based on the total cost version of equation (9). Unlike conventional trend estimates, these measures of nonneutral technical change are unconstrained time series for each input. This is a distinguishing feature of the general index that facilitates evaluation of potential sources. Subsequent analysis based on the $\mathrm{A}_{\mathrm{it}}$ time series alone would relate aggregate employment patterns to manufacturingwide diffusion of technical advances.

On the other hand, a panel data approach makes use of additional information on non-uniform adoption patterns across the original units of observation. The input-specific indices of technical change, $\mu_{\text {ist }}$ based on equation (12), provide a panel of estimates that form the basis for subsequent analysis. A system of regression equations is formed for each input (i) in which the $\mu_{\text {ist }}$ series are regressed on a common set of proposed sources of technical change $\left(Z_{\mathrm{st}}\right)$. Irrespective of possible correlation of errors across equations, with common regressors the ISURE procedure is equivalent to OLS.

Our main objective is to demonstrate how the general index approach might be used; however, the proposed elements of technical change in this exercise relate to measures that have appeared elsewhere in the literature. We consider nine measures, each observable at the 2-digit SIC level throughout our sample period. The high-tech capital measure found in other studies is a collection of several different investment accounts. Separate $\mathrm{Z}_{\mathrm{st}}$ variables are introduced for personal computer \& network equipment, mainframe \& equipment, software, communications equipment, instruments and office equipment. In each case, we form the ratio of investment in a specific category to total new investment.

The Bureau of Economic Analysis also provides investment information on a range of asset classes. Estimates of the average age of industrial machinery are included to capture vintage upgrading of capital equipment. A separate variable for industrial equipment and structures records new investment in these categories as a proportion of total investment. The ratio of business service outsourcing expenses to total 
cost may proxy for innovations in organizational boundaries or simply address input measurement error.

Following Morrison Paul and Siegel (2001), we derive our outsourcing measure from the Bureau of Labor Statistics KLEMS file.

Parameter estimates for production and nonproduction labor are presented in Table 6, with relative labor demand results formed as cross-equation linear combinations. Cost shares for both groups of labor decrease with an increase in personal computer and network investments. This response is skill-biased with the total cost share of production labor experiencing a relative decline. New investments in communication equipment are nonproduction-using and nonneutral across the labor groups. Significant skill-biased responses are also evident for industrial equipment, office equipment, outsourcing, software and instruments.

Instrument-intensive investment may provide a unique indicator of automated process adoption in manufacturing plants. This category includes a wide variety of instruments for measurement (mechanical counters, temperature sensors, infrared scanners), analysis (flow instruments, integrated circuit testers, mass spectrometers), display (pressure gauges, digital displays) and manufacturing process control (pneumatic switches, boiler controls). Some of the most significant forms of labor-saving automation in manufacturing rely on a straightforward combinations of measurement and process control. Furthermore, some form of measurement and, in some cases, analysis would seem a prerequisite for quantitative analysis of any manufacturing process. Thus, instrument-intensive investment could serve as precursor for initial information technology investments and for subsequent adoption of advanced manufacturing technologies as described by Doms, Dunne and Trosky (1997).

Several of the items counted in instruments represent laboratory equipment and may well be correlated with R\&D expenditures. On the other hand, the significant skill-bias associated with instruments, personal computers or office equipment may simply reflect complementarity between one 
group of labor and disaggregate capital inputs. An increased share of office-based (nonproduction) labor due to unexplained sources is associated with increased purchases of personal computers and other office equipment. This concern would be consistent with cautionary notes regarding pre-adoption skill patterns in Doms, Dunne and Trosky (1997) and Berman, Bound and Machin (1998).

\section{Decomposing Share Changes}

The post-1983 absence of SBTC in our results does not preclude within-industry labor demand shifts. Relative labor demand may be a function of input prices, output, and technical change as long as these primary determinants are not restricted from entering the input demand system. We separate relative share changes, as in (3), (6) and (10), into these components. The implications of our estimates from the total cost - general index specification appear in Table 7 for selected time periods of interest.

Technical change is singularly responsible for the declining relative share for production workers over the 1973-1979 period. The magnitude of technical change reflects declining production share despite favorable price and output conditions. In particular, substantial price increases for both energy and capital encourage substitution toward production labor. The relative decline in production labor share accelerates during 1979-1983; however, the role of technical change is muted when compared to the preceding time period. A recession-driven decline in output and a large unexplained element contribute to continued deterioration of the "blue collar" share.

Over the 1983-1989 period technical change is an insignificant factor. All of the skill-biased decline can be explained by price-induced substitution. Energy prices are falling over this period and energy is a substitute for production labor. Relative wages for production labor are falling as well and this tends to further reduce the production labor share. The direct negative effect of a declining wage on cost share dominates indirect employment gains through substitution responses. As shown in previous studies 
by Levy and Jondrow (1986) and Betts (1997), price-induced substitution and nonhomothetic output responses may overshadow nonneutral technical change.

In the tradition of the microeconomic production literature, we take relative wage patterns to be exogenous to the decisions of our 4-digit SIC industries. This is a significant departure from Berman, Bound and Griliches (1994) and Machin and Van Reenen (1998) and deserves further consideration. Relative wages for production workers in our sample do decline sharply from 1983 onward. By our estimates, this reduces the relative cost share of production labor. There is a simultaneity concern to the extent that labor demand shifts driven by technical change at the 4-digit SIC level in manufacturing are responsible for the wage patterns. There are a host of potential contributing sources for the observed wage patterns including labor supply concerns, economy-wide technical change or issues related to labor market institutions (Fortin and Lemieux (1997), Goux and Maurin (2000), Wolff (2002)). The econometric hazards of excluding wages from the cost share regression are exacerbated to the extent that wage patterns are determined by forces such as these that are exogenous to our detailed manufacturing industries.

In the lower panel of Table 7 we examine the implications of the proposed sources of technical change on observed relative share changes. Can we explain relative share changes that cannot be attributed to price and output responses? It may be worth noting at the outset that the unexplained portion is substantial in each time period. Our nine proposed sources offer only a partial glimpse of actual determinants within the "black box" of nonneutral technical change. A clear advantage of the general index approach over direct inclusion of these proxies in the system of cost shares is that our first round estimates remain unaffected by our inability to completely account for the sources of technical change.

Instruments are the most important element over the 1973-1979 period. Communication equipment, software, personal computers and instruments all contribute to skill-biased technical change over 1979-1983. Personal computers first appear in the manufacturing data in 1982 and overtake new 
mainframe spending by 1994. Personal computers and software (not restricted to PC's) become increasingly important during the 1979-1983 and 1983-1989 periods as contributors to SBTC. Thus, we are able to reconcile our findings with Berman, Bound and Griliches. We find significant technical change through 1983 that would be included in their 1979-1987 analysis. We also find SBTC responses to personal computers and software that extend through the late 1980's despite the overall finding of insignificant technical change for that period.

\section{Concluding Observations}

The production literature offers a system-based trend approach to the measurement of nonneutral technical change. Due to overriding interest in the sources of skill-biased technical change, a reduced form proxy approach has become more prevalent. The general index approach conveys the advantages of both alternatives and provides an effective framework for evaluating skill-biased technical change in the context of a flexible cost system. This approach offers an especially useful empirical framework for industryspecific studies where proposed sources of technical change can be identified.

In our application to U.S. manufacturing industries we establish an explicit time path showing significant production labor-saving technical change ending by 1983 . This would seem to diminish the case for SBTC in manufacturing industries as a contemporary source of 1980's U.S. earnings patterns. Our exploration of the sources of technical change reveals a number of contributing elements including instruments, communications equipment, personal computers, software and a substantial unexplained portion. The particular timing and diverse sources identified here add emphasis to a concluding statement in Berman, Bound and Griliches (1994): “These trends support the notion that, historically, biased technological change has been an important source of increased (relative) demand for skilled labor. They also suggest that we avoid exaggerating the uniqueness of the computer revolution." 


\section{Footnotes:}

Chris Abrams provided valuable research assistance. We appreciate comments offered by several participants at the "Current Developments in Productivity and Efficiency Measurement" conference at the University of Georgia and the 2003 Econometric Society North American Meetings at Northwestern University. The authors would also like to thank two anonymous reviewers, Jeff Dorfman and seminar participants at Texas A\&M University and Illinois State University. 
References

Acemoglu, D., 2002. Technical change, inequality and the labor market, Journal of Economic Literature 40, 7-72.

Baltagi, B., Griffin, J., 1988. A general index of technical change, Journal of Political Economy 96, 2041.

Baltagi, B., Griffin, J., Rich, D., 1995. The measurement of firm-specific indexes of technical change, Review of Economics and Statistics 77, 654-663.

Berman, E., Bound, J., Griliches, Z., 1994. Changes in the demand for skilled labor within U.S. manufacturing: evidence from the annual survey of manufactures, Quarterly Journal of Economics 109, 367-397.

Berman, E., Bound, J., Machin, S., 1998. Implications of skill-biased technological change: international evidence, Quarterly Journal of Economics 113, 1245-1280.

Berndt, E., Morrison, C., 1994. High-tech capital formation and economic performance in U.S. manufacturing industries: an exploratory analysis, Journal of Econometrics 65, 9-43.

Betts, J., 1997. The skill bias of technological change in Canadian manufacturing industries, Review of Economics and Statistics 79, 146-150.

Binswanger, H., 1974. The measurement of technical change biases with many factors of production, American Economic Review 64, 964-976.

Bound, J., Johnson, G., 1992. Changes in the structure of wages in the 1980's: an evaluation of alternative explanations, American Economic Review 82, 371-392.

Breusch, T., Pagan, A., 1980. The LM test and its applications to model specification in econometrics, Review of Economic Studies 47, 239-254.

Doms, M., Dunne, T., Troske, K., 1997. Workers, wages and technology, Quarterly Journal of Economics $112,253-290$.

Fortin, N., Lemieux, T., 1997. Institutional changes and rising wage inequality: is there a linkage, Journal of Economic Perspectives 11, 75-96.

Goux, D., Maurin, E., 2000. The decline in demand for unskilled labor: an empirical analysis method and its application to France, Review of Economics and Statistics 82, 596-607.

Johnson, G., 1997. Changes in earnings inequality: the role of demand shifts, Journal of Economic Perspectives 11, 41-54. 
Kumbhakar, S., 2002. Decomposition of technical change into input-specific components: a factor augmenting approach, Japan and the World Economy 14, 243-264.

Levy, R., Jondrow, J., 1986. The adjustment of employment to technical change in the steel and auto industries, Journal of Business 59, 475-491.

Machin, S., Van Reenen, J., 1998. Technology and changes in the skill structure: evidence from seven OECD countries, Quarterly Journal of Economics 113, 1215-1244.

Morrison, C., Berndt, E., 1981. Short-run labor productivity in a dynamic model, Journal of Econometrics $16,339-365$.

Morrison Paul, C., Siegel, D., 2001. The impacts of technology, trade and outsourcing on employment and labor composition, Scandanavian Journal of Economics 103, 241-264.

Murphy, K., Welch, F., 1992. The structure of wages, Quarterly Journal of Economics 107, 285-326.

Murphy, K., Welch, F., 1993. Occupational change and the demand for skill, 1940-1990, American Economic Review 83, 122-126.

Nissim, J., 1984. The price responsiveness of the demand for labor by skill: British mechanical engineering, 1963-1978, Economic Journal 94, 812-825.

Roberts, M., Skoufias, E., 1997. The long-run demand for skilled and unskilled labor in Colombian manufacturing plants, Review of Economics and Statistics 79, 330-334.

Thomsen, T., 2000. Short cuts to dynamic factor demand modeling, Journal of Econometrics 97, 1-23.

Wolff, E., 2002. The impact of it investment on income and wealth inequality in the postwar U.S. economy, Information Economics and Policy 14, 233-251. 
Table 1: Factor Demand System Parameter Estimates

\begin{tabular}{|c|c|c|c|c|c|c|c|}
\hline$\alpha_{p}$ & $.421(.007)$ & $\eta_{p, 63}$ & $.002(.003)$ & $\alpha_{n}$ & $.108(.008)$ & $\eta_{\mathrm{n}, 63}$ & $.001(.003)$ \\
\hline$\gamma_{\mathrm{pp}}$ & $-.021(.001)$ & $\eta_{\mathrm{p}, 69}$ & $-.038(.003)$ & $\gamma_{\mathrm{np}}$ & $-.010(.001)$ & $\eta_{\mathrm{n}, 69}$ & $-.020(.003)$ \\
\hline$\gamma_{\mathrm{pn}}$ & $-.010(.001)$ & $\eta_{p, 73}$ & $-.081(.004)$ & $\gamma_{\mathrm{nn}}$ & $.032(.002)$ & $\eta_{\mathrm{n}, 73}$ & $-.040(.003)$ \\
\hline$\gamma_{\mathrm{pe}}$ & $.042(.001)$ & $\eta_{\mathrm{p}, 79}$ & $-.182(.004)$ & $\gamma_{\text {ne }}$ & $.009(.001)$ & $\eta_{\mathrm{n}, 79}$ & $-.080(.003)$ \\
\hline$\gamma_{\mathrm{pm}}$ & $-.098(.001)$ & $\eta_{p, 83}$ & $-.224(.004)$ & $\gamma_{\mathrm{nm}}$ & $-.053(.001)$ & $\eta_{\mathrm{n}, 83}$ & $-.089(.003)$ \\
\hline$\gamma_{\mathrm{pk}}$ & $.045(.001)$ & $\eta_{\mathrm{p}, 89}$ & $-.237(.004)$ & $\gamma_{\mathrm{nk}}$ & $.021(.001)$ & $\eta_{\mathrm{n}, 89}$ & $-.098(.003)$ \\
\hline$\gamma_{\mathrm{py}}$ & $.084(.001)$ & $\eta_{\mathrm{p}, 93}$ & $-.233(.004)$ & $\gamma_{\text {ny }}$ & $.041(.001)$ & $\eta_{\mathrm{n}, 93}$ & $-.094(.003)$ \\
\hline$\alpha_{\mathrm{e}}$ & $-.140(.005)$ & $\eta_{\mathrm{e}, 63}$ & $-.007(.002)$ & $\alpha_{\mathrm{m}}$ & $.713(.007)$ & $\eta_{\mathrm{m}, 63}$ & $.013(.005)$ \\
\hline$\gamma_{\text {ep }}$ & $.042(.001)$ & $\eta_{\mathrm{e}, 69}$ & $-.002(.002)$ & $\gamma_{\mathrm{mp}}$ & $-.098(.001)$ & $\eta_{\mathrm{m}, 69}$ & $.060(.005)$ \\
\hline$\gamma_{\text {en }}$ & $.009(.001)$ & $\eta_{\mathrm{e}, 73}$ & $-.004(.002)$ & $\gamma_{\mathrm{mn}}$ & $-.053(.001)$ & $\eta_{\mathrm{m}, 73}$ & $.117(.005)$ \\
\hline$\gamma_{\text {ee }}$ & $-.001(.001)$ & $\eta_{e, 79}$ & $-.002(.002)$ & $\gamma_{\mathrm{me}}$ & $-.026(.001)$ & $\eta_{\mathrm{m}, 79}$ & $.249(.005)$ \\
\hline$\gamma_{\mathrm{em}}$ & $-.026(.001)$ & $\eta_{\mathrm{e}, 83}$ & $-.006(.002)$ & $\gamma_{\mathrm{mm}}$ & $.215(.002)$ & $\eta_{\mathrm{m}, 83}$ & $.303(.005)$ \\
\hline$\gamma_{\mathrm{ek}}$ & $-.025(.001)$ & $\eta_{e, 89}$ & $-.021(.002)$ & $\gamma_{\mathrm{mk}}$ & $-.038(.001)$ & $\eta_{\mathrm{m}, 89}$ & $.358(.006)$ \\
\hline$\gamma_{\text {ey }}$ & $.022(.001)$ & $\eta_{\mathrm{e}, 93}$ & $-.029(.002)$ & $\gamma_{\mathrm{my}}$ & $-.185(.002)$ & $\eta_{\mathrm{m}, 93}$ & $.378(.006)$ \\
\hline$\alpha_{\mathrm{k}}$ & $-.102(.007)$ & $\eta_{\mathrm{k}, 63}$ & $-.010(.002)$ & rmse $_{\mathrm{p}}$ & .051 & $\mathrm{rsq}_{\mathrm{p}}$ & .629 \\
\hline$\gamma_{\mathrm{kp}}$ & $.045(.001)$ & $\eta_{\mathrm{k}, 69}$ & $.001(.002)$ & rmse $_{n}$ & .038 & $\mathrm{rsq}_{\mathrm{n}}$ & .574 \\
\hline$\gamma_{\mathrm{kn}}$ & $.021(.001)$ & $\eta_{\mathrm{k}, 73}$ & $.008(.002)$ & $\mathrm{rmse}_{\mathrm{e}}$ & .027 & $\mathrm{rsq}_{\mathrm{e}}$ & .416 \\
\hline$\gamma_{\mathrm{ke}}$ & $-.025(.001)$ & $\eta_{\mathrm{k}, 79}$ & $.015(.002)$ & rmse $_{k}$ & .031 & $\mathrm{rsq}_{\mathrm{k}}$ & .584 \\
\hline$\gamma_{\mathrm{km}}$ & $-.038(.001)$ & $\eta_{\mathrm{k}, 83}$ & $.016(.003)$ & & & & \\
\hline$\gamma_{\mathrm{kk}}$ & $-.004(.001)$ & $\eta_{\mathrm{k}, 89}$ & $-.002(.003)$ & & & & \\
\hline$\gamma_{\text {ky }}$ & $.031(.001)$ & $\eta_{\mathrm{k}, 93}$ & $-.022(.002)$ & & & & \\
\hline
\end{tabular}

Parameter estimates based on ISURE estimation of factor demand system based on total cost with general index representation of technical change. Subscripts refer to (p) production workers, (n) nonproduction workers, (e) energy, (m) materials, and (k) capital. Goodness-of-fit measures (rmse, rsq) are reported for each equation.

Selected $\left(\eta_{\text {it }}\right)$ time index estimates are presented while industry fixed effect estimates are omitted. Standard errors are given in parentheses. 
Table 2: Labor Demand Elasticities

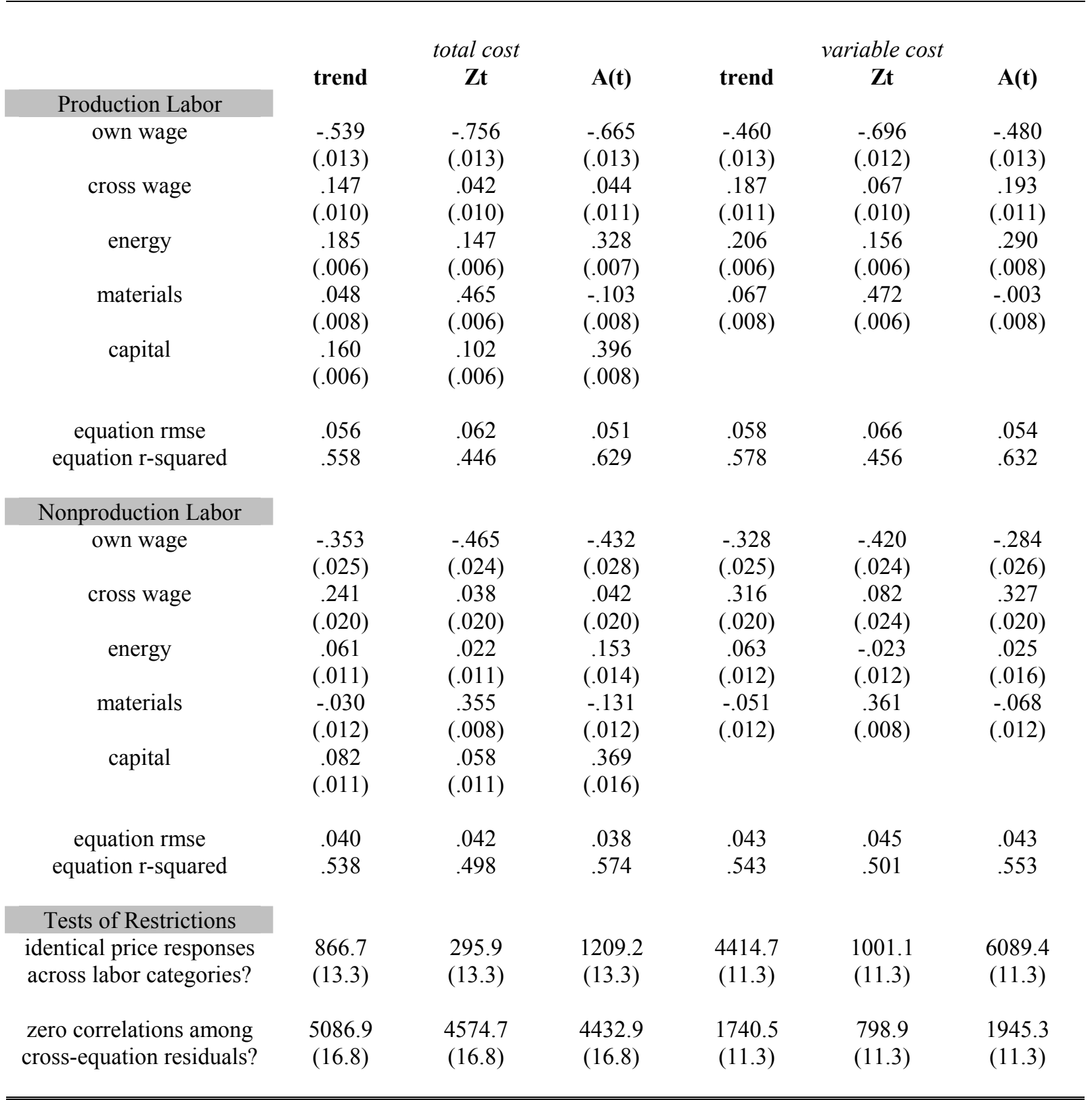

Elasticities are calculated at each observation. Values in table represent aggregation across years of payrollweighted annual means. Associated standard errors are given in parentheses. Chi-square statistics and critical values are presented for tests of restrictions. 
Table 3: Relative Share Estimates

\begin{tabular}{|c|c|c|c|c|c|c|}
\hline \multirow{3}{*}{ Relative Share (Sp-Sn) } & \multicolumn{3}{|c|}{ total cost } & \multicolumn{3}{|c|}{ variable cost } \\
\hline & trend & $\mathbf{Z t}$ & $\mathbf{A}(\mathbf{t})$ & trend & $\mathbf{Z t}$ & $\mathbf{A}(\mathbf{t})$ \\
\hline & & & & & & \\
\hline production wage & $\begin{array}{c}.034 \\
(003)\end{array}$ & $\begin{array}{c}.019 \\
(003)\end{array}$ & $\begin{array}{c}.031 \\
(003)\end{array}$ & $\begin{array}{c}.042 \\
(003)\end{array}$ & $\begin{array}{c}.025 \\
(003)\end{array}$ & $\begin{array}{c}.038 \\
(003)\end{array}$ \\
\hline nonproduction wage & $\begin{array}{l}-.034 \\
(.003)\end{array}$ & $\begin{array}{l}-.041 \\
(.003)\end{array}$ & $\begin{array}{l}-.043 \\
(.003)\end{array}$ & $\begin{array}{l}-.033 \\
(.003)\end{array}$ & $\begin{array}{l}-.044 \\
(.003)\end{array}$ & $\begin{array}{l}-.036 \\
(.003)\end{array}$ \\
\hline energy & $\begin{array}{l}.020 \\
(.001)\end{array}$ & $\begin{array}{l}.017 \\
(.001)\end{array}$ & $\begin{array}{l}.033 \\
(.002)\end{array}$ & $\begin{array}{l}.024 \\
(.002)\end{array}$ & $\begin{array}{l}.023 \\
(.002)\end{array}$ & $\begin{array}{l}.040 \\
(.002)\end{array}$ \\
\hline materials & $\begin{array}{l}-.032 \\
(.001)\end{array}$ & $\begin{array}{l}-.001 \\
(.001)\end{array}$ & $\begin{array}{l}-.045 \\
(.002)\end{array}$ & $\begin{array}{l}-.033 \\
(.002)\end{array}$ & $\begin{array}{l}-.004 \\
(.001)\end{array}$ & $\begin{array}{l}-.042 \\
(.002)\end{array}$ \\
\hline capital (Pk) & $\begin{array}{c}.012 \\
(.001)\end{array}$ & $\begin{array}{l}.006 \\
(.001)\end{array}$ & $\begin{array}{l}.024 \\
(.002)\end{array}$ & & & \\
\hline capital (K) & & & & $\begin{array}{l}.018 \\
(.001)\end{array}$ & $\begin{array}{l}.016 \\
(.001)\end{array}$ & $\begin{array}{l}.022 \\
(.001)\end{array}$ \\
\hline output & $\begin{array}{l}.021 \\
(.001)\end{array}$ & $\begin{array}{l}-.009 \\
(.001)\end{array}$ & $\begin{array}{l}.035 \\
(.002)\end{array}$ & $\begin{array}{l}.005 \\
(.002)\end{array}$ & $\begin{array}{l}-.022 \\
(.002)\end{array}$ & $\begin{array}{l}.010 \\
(.002)\end{array}$ \\
\hline \multicolumn{7}{|l|}{ Technical Change } \\
\hline production share & $\begin{array}{l}-.0067 \\
(.0001)\end{array}$ & $\begin{array}{l}-.0010 \\
(.0000)\end{array}$ & $\begin{array}{l}-.0067 \\
(.0001)\end{array}$ & $\begin{array}{l}-.0071 \\
(.0001)\end{array}$ & $\begin{array}{l}-.0010 \\
(.0000)\end{array}$ & $\begin{array}{l}-.0063 \\
(.0001)\end{array}$ \\
\hline nonproduction share & $\begin{array}{l}-.0028 \\
(.0001)\end{array}$ & $\begin{array}{l}-.0003 \\
(.0000)\end{array}$ & $\begin{array}{l}-.0028 \\
(.0001)\end{array}$ & $\begin{array}{l}-.0031 \\
(.0001)\end{array}$ & $\begin{array}{l}-.0003 \\
(.0000)\end{array}$ & $\begin{array}{l}-.0027 \\
(.0001)\end{array}$ \\
\hline skill-biased $\left(\gamma_{\mathrm{pt}}-\gamma_{\mathrm{nt}}\right)$ & $\begin{array}{l}-.0039 \\
(.0001)\end{array}$ & $\begin{array}{l}-.0007 \\
(.0000)\end{array}$ & $\begin{array}{l}-.0038 \\
(.0001)\end{array}$ & $\begin{array}{l}-.0040 \\
(.0001)\end{array}$ & $\begin{array}{l}-.0007 \\
(.0000)\end{array}$ & $\begin{array}{l}-.0036 \\
(.0001)\end{array}$ \\
\hline \multicolumn{7}{|l|}{ Tests of Restrictions } \\
\hline $\begin{array}{c}\text { homothetic response } \\
\text { to output? }\end{array}$ & $\begin{array}{c}8145.9 \\
(13.3)\end{array}$ & $\begin{array}{l}3791.1 \\
(13.3)\end{array}$ & $\begin{array}{c}10014.9 \\
(13.3)\end{array}$ & $\begin{array}{l}3007.7 \\
(11.3)\end{array}$ & $\begin{array}{l}322.7 \\
(11.3)\end{array}$ & $\begin{array}{c}4308.8 \\
(11.3)\end{array}$ \\
\hline $\begin{array}{l}\text { hicks-neutral } \\
\text { technical change? }\end{array}$ & $\begin{array}{c}9055.1 \\
(13.3)\end{array}$ & $\begin{array}{c}2332.1 \\
(13.3)\end{array}$ & $\begin{array}{l}14268.0 \\
(190.9)\end{array}$ & $\begin{array}{c}10679.8 \\
(11.3)\end{array}$ & $\begin{array}{r}2605.8 \\
(11.3)\end{array}$ & $\begin{array}{l}13759.5 \\
(148.6)\end{array}$ \\
\hline $\begin{array}{c}\text { skill-neutral } \\
\text { technical change? }\end{array}$ & $\begin{array}{c}1547.1 \\
(6.6)\end{array}$ & $\begin{array}{l}779.8 \\
(6.6)\end{array}$ & $\begin{array}{c}2085.2 \\
(59.9)\end{array}$ & $\begin{array}{c}1448.6 \\
(6.6)\end{array}$ & $\begin{array}{c}838.6 \\
(6.6)\end{array}$ & $\begin{array}{c}1833.7 \\
(59.9)\end{array}$ \\
\hline
\end{tabular}

Relative share estimates given in the table are cross-equation linear combinations of estimated parameters. Values for technical change represent average annual share changes based on full sample estimates.

Chi-square statistics and critical values are presented for tests of restrictions. 

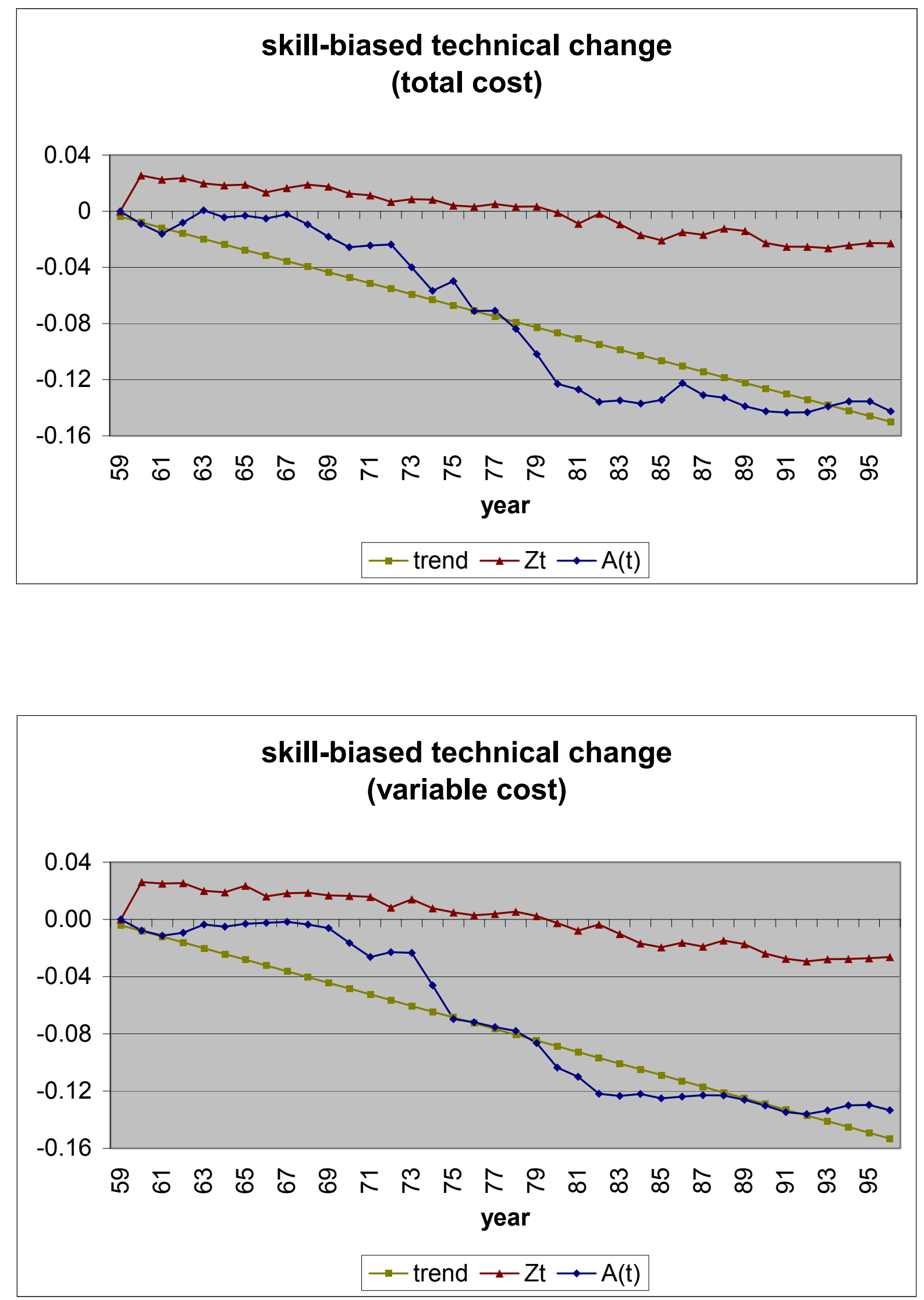
Table 4: Skill-Biased Technical Change (selected years)

\begin{tabular}{llclc}
\hline \hline & & & & \\
& SBTC & Standard Error & $z$ & probability \\
$1959-1963$ & .001 & $(.004)$ & 0.16 & .874 \\
$1963-1969$ & -.019 & $(.005)$ & -4.18 & .000 \\
$1969-1973$ & -.022 & $(.004)$ & -4.94 & .000 \\
$1973-1979$ & -.062 & $(.005)$ & -13.48 & .000 \\
$1979-1983$ & -.033 & $(.004)$ & -7.46 & .000 \\
$1983-1989$ & -.004 & $(.004)$ & -0.95 & .341 \\
$1989-1993$ & -.000 & $(.004)$ & -0.04 & .969 \\
$1993-1996$ & -.004 & $(.004)$ & -0.80 & .423 \\
\hline \hline
\end{tabular}

Point-to-point estimates for skill-biased technical change.

Estimates represent cross-equation linear combinations from total cost - general index specification. 
Table 5: Skill-Biased Technical Change by Industry

\begin{tabular}{|c|c|c|c|c|}
\hline \multirow[b]{2}{*}{ 2-digit industry } & \multicolumn{3}{|c|}{ range over 4-digit industries } & \multirow[b]{2}{*}{ payroll weight } \\
\hline & mean & minimum & maximum & \\
\hline industrial machinery \& equipment & -.0041 & -.0108 & -.0012 & $12.1 \%$ \\
\hline printing and publishing & -.0054 & -.0086 & -.0028 & $6.8 \%$ \\
\hline fabricated metal products & -.0041 & -.0086 & -.0013 & $8.3 \%$ \\
\hline electrical and electronic equipment & -.0039 & -.0096 & -.0014 & $8.2 \%$ \\
\hline transportation equipment & -.0039 & -.0081 & +.0008 & $7.5 \%$ \\
\hline instruments and related products & -.0053 & -.0105 & +.0002 & $5.3 \%$ \\
\hline primary metal industries & -.0036 & -.0067 & -.0022 & $6.7 \%$ \\
\hline food and kindred products & -.0025 & -.0047 & +.0012 & $7.9 \%$ \\
\hline chemical and allied products & -.0033 & -.0070 & -.0012 & $5.8 \%$ \\
\hline auto manufacturing & -.0031 & -.0048 & -.0021 & $5.5 \%$ \\
\hline apparel and other textile products & -.0040 & -.0065 & -.0012 & $3.9 \%$ \\
\hline stone, clay, glass and concrete & -.0048 & -.0081 & -.0009 & $3.0 \%$ \\
\hline paper and allied products & -.0032 & -.0063 & -.0019 & $3.8 \%$ \\
\hline rubber and plastics & -.0033 & -.0074 & -.0024 & $3.6 \%$ \\
\hline lumber and wood products & -.0039 & -.0055 & -.0016 & $2.8 \%$ \\
\hline textile mill products & -.0035 & -.0047 & -.0023 & $3.1 \%$ \\
\hline miscellaneous manufacturing & -.0044 & -.0072 & -.0018 & $1.8 \%$ \\
\hline furniture and fixtures & -.0038 & -.0048 & -.0026 & $1.9 \%$ \\
\hline leather and leather products & -.0047 & -.0068 & -.0023 & $0.8 \%$ \\
\hline petroleum and coal products & -.0029 & -.0036 & -.0021 & $1.0 \%$ \\
\hline tobacco manufactures & -.0042 & -.0074 & -.0028 & $0.3 \%$ \\
\hline U.S. manufacturing & -.0039 & -.0108 & +.0012 & $100.0 \%$ \\
\hline
\end{tabular}

Skill-biased technical change (annual average) by industry derived from total cost - general index specification. Industries ordered by relative contribution to manufacturing payroll-weighted average. 
Table 6: Proposed Sources of Skill-Biased Technical Change

\begin{tabular}{|c|c|c|c|}
\hline & Production & Nonproduction & Relative $L D$ \\
\hline personal computer \& network & $-1.838(.403)$ & $-.744(.248)$ & $-1.095(.265)$ \\
\hline mainframe \& equipment & $.100(.175)$ & $.228(.108)$ & $-.128(.115)$ \\
\hline software & $-.230(.198)$ & $.215(.122)$ & $-.445(.130)$ \\
\hline communications equipment & $-.179(.115)$ & $.421(.071)$ & $-.600(.076)$ \\
\hline office equipment & $.262(.099)$ & $.625(.061)$ & $-.363(.065)$ \\
\hline instruments & $-1.258(.082)$ & $-.236(.051)$ & $-1.023(.054)$ \\
\hline age of machinery & $-.008(.002)$ & $-.009(.001)$ & $.001(.001)$ \\
\hline industrial equipment \& structures & $.002(.037)$ & $.106(.023)$ & $-.104(.024)$ \\
\hline business service outsourcing & $-.215(.050)$ & $-.132(.031)$ & $-.083(.033)$ \\
\hline constant & $.060(.035)$ & $-.053(.021)$ & $.113(.023)$ \\
\hline equation rmse & .068 & .042 & \\
\hline equation r-squared & .577 & .380 & \\
\hline
\end{tabular}

Dependent variable $\mathrm{A}_{\text {ist }}$ derived from total cost - general index specification.

OLS estimates (based on 798 observations) with standard errors in parentheses. 


\section{Table 7: Decomposition of Relative Share Changes}

1973-1979

Change in Relative Share
output responses
price-induced
technical change $\left(\mathrm{A}_{\mathrm{t}}\right)$
unexplained

$$
\begin{array}{r}
-.022 \\
+.004 \\
+.038 \\
-.062
\end{array}
$$$$
-.002
$$

1979-1983

$$
-.028
$$$$
-.003
$$$$
+.020
$$$$
-.033
$$$$
-.012
$$

1983-1989

$-.013$

$+.007$

$-.013$

$-.004$

$-.003$

$\begin{array}{cccc}\text { Technical Change }\left(\mathbf{A}_{\text {ist }}\right) & \mathbf{- . 0 6 5} & \mathbf{- . 0 3 7} & \mathbf{- . 0 0 5} \\ \text { personal computer } & .000 & -.012 & -.013 \\ \text { mainframe } & -.001 & -.001 & -.000 \\ \text { software } & -.001 & -.005 & -.013 \\ \text { communications } & -.007 & -.007 & -.000 \\ \text { office equipment } & -.003 & -.002 & +.004 \\ \text { instruments } & -.017 & -.008 & -.004 \\ \text { age of machinery } & .000 & .000 & .000 \\ \text { industrial equipment } & +.004 & +.006 & +.003 \\ \text { outsourcing } & -.001 & -.000 & -.001 \\ \text { unexplained } & -.041 & -.009 & +.019\end{array}$

Marginal changes evaluated for each industry based on total cost specification estimates.

Annual results represent payroll-weighted aggregation of industry-level results. 


\section{IZA Discussion Papers}

\begin{tabular}{|c|c|c|c|c|}
\hline No. & Author(s) & Title & Area & Date \\
\hline 827 & $\begin{array}{l}\text { H. Buddelmeyer } \\
\text { E. Skoufias }\end{array}$ & $\begin{array}{l}\text { An Evaluation of the Performance of Regression } \\
\text { Discontinuity Design on PROGRESA }\end{array}$ & 6 & $07 / 03$ \\
\hline 828 & $\begin{array}{l}\text { D. Checchi } \\
\text { T. Jappelli }\end{array}$ & School Choice and Quality & 3 & $07 / 03$ \\
\hline 829 & $\begin{array}{l}\text { J. J. Heckman } \\
\text { X. Li }\end{array}$ & $\begin{array}{l}\text { Selection Bias, Comparative Advantage and } \\
\text { Heterogeneous Returns to Education: Evidence } \\
\text { from China in } 2000\end{array}$ & 6 & $07 / 03$ \\
\hline 830 & T. J. Hatton & $\begin{array}{l}\text { Emigration from the UK, } 1870-1913 \text { and } 1950- \\
1998\end{array}$ & 1 & $07 / 03$ \\
\hline 831 & $\begin{array}{l}\text { J. H. Abbring } \\
\text { G. J. van den Berg }\end{array}$ & $\begin{array}{l}\text { Analyzing the Effect of Dynamically Assigned } \\
\text { Treatments Using Duration Models, Binary } \\
\text { Treatment Models, and Panel Data Models }\end{array}$ & 6 & $07 / 03$ \\
\hline 832 & P.-C. Michaud & Joint Labour Supply Dynamics of Older Couples & 3 & $07 / 03$ \\
\hline 833 & H. Gersbach & $\begin{array}{l}\text { Structural Reforms and the Macroeconomy: The } \\
\text { Role of General Equilibrium Effects }\end{array}$ & 2 & $07 / 03$ \\
\hline 834 & $\begin{array}{l}\text { T. Boeri } \\
\text { J. I. Conde-Ruiz } \\
\text { V. Galasso }\end{array}$ & $\begin{array}{l}\text { Protecting Against Labour Market Risk: } \\
\text { Employment Protection or Unemployment } \\
\text { Benefits? }\end{array}$ & 3 & 07/03 \\
\hline 835 & $\begin{array}{l}\text { G. Joseph } \\
\text { O. Pierrard } \\
\text { H. R. Sneessens }\end{array}$ & $\begin{array}{l}\text { Job Turnover, Unemployment and Labor Market } \\
\text { Institutions }\end{array}$ & 3 & 07/03 \\
\hline 836 & M.-S. Yun & $\begin{array}{l}\text { A Simple Solution to the Identification Problem } \\
\text { in Detailed Wage Decompositions }\end{array}$ & 3 & $07 / 03$ \\
\hline 837 & W. Schnedler & $\begin{array}{l}\text { What You Always Wanted to Know About } \\
\text { Censoring But Never Dared to Ask - Parameter } \\
\text { Estimation for Censored Random Vectors }\end{array}$ & 6 & $07 / 03$ \\
\hline 838 & $\begin{array}{l}\text { S. Girma } \\
\text { H. Görg } \\
\text { E. Strobl }\end{array}$ & $\begin{array}{l}\text { Government Grants, Plant Survival and } \\
\text { Employment Growth: A Micro-Econometric } \\
\text { Analysis }\end{array}$ & 6 & $07 / 03$ \\
\hline 839 & $\begin{array}{l}\text { A. Bassanini } \\
\text { G. Brunello }\end{array}$ & $\begin{array}{l}\text { Is Training More Frequent When Wage } \\
\text { Compression is Higher? Evidence from the } \\
\text { European Community Household Panel }\end{array}$ & 6 & 08/03 \\
\hline 840 & $\begin{array}{l}\text { E. Koskela } \\
\text { R. Stenbacka }\end{array}$ & $\begin{array}{l}\text { Equilibrium Unemployment Under Negotiated } \\
\text { Profit Sharing }\end{array}$ & 1 & 08/03 \\
\hline 841 & $\begin{array}{l}\text { B. H. Baltagi } \\
\text { D. P. Rich }\end{array}$ & $\begin{array}{l}\text { Skill-Biased Technical Change in U.S. } \\
\text { Manufacturing: A General Index Approach }\end{array}$ & 1 & 08/03 \\
\hline
\end{tabular}

An updated list of IZA Discussion Papers is available on the center's homepage www.iza.org. 